This is the authors' final version of the paper published in:

Asia Pacific Journal of Tourism Research

Original publication available at:

http://dx.doi.org/10.1080/10941665.2018.1561478

You can cite this paper as:

Femenia-Serra, F. \& Ivars-Baidal, J.A. (2018). Do Smart Tourism Destinations Really Work?

The Case of Benidorm. Asia Pacific Journal of Tourism Research (forthcoming), http://dx.doi.org/10.1080/10941665.2018.1561478

\title{
Do Smart Tourism Destinations Really Work? The Case of Benidorm
}

\section{Francisco Femenia-Serra* \& Josep A. Ivars-Baidal}

Tourism Research Institute, University of Alicante, Campus San Vicente del Raspeig, 03090 Alicante, Spain

*Corresponding author. Tel.: +34 965903400(3726); fax: +34 965909552

Email: paco.femenia@ua.es (F. Femenia-Serra), josep.ivars@ua.es (J.A. Ivars-Baidal)

Abstract: Smart Destinations (SDs) have gained momentum in tourism research, but despite the growing body of literature devoted to the topic, some critical dimensions continue to be underresearched. The real fulfilment of two of the main objectives of SDs, namely enhancing tourists' experiences and improving destinations management, remains largely unknown. In line with this, the actual impact of technological smart solutions implemented by DMOs in SDs over these two scopes has not been sufficiently addressed from a holistic perspective. In this paper, by taking as a relevant case the destination of Benidorm, its smart destination strategy and solutions, we investigate whether and how these smart destination efforts are actually transforming the destination management processes and tourists' experiences. Through a sequence of qualitative methods including (i) documentary and other secondary data analysis, (ii) in-depth interviews with DMO representatives and key informants and (iii) in-depth interviews with tourists visiting the destination, rich data was 
obtained, systematically analysed and triangulated. The findings pose critical lessons for destinations in their transition towards smartness, especially for policy makers, and shed light on the effects of smart solutions on tourist experiences.

Keywords: Smart Tourism Destination; Smart solutions; DMO; Tourist experience; Tourist Destination; Benidorm; Smart Tourism

\section{Introduction}

Smart Destinations (SDs) are gaining recognition in tourism research as a valuable contribution to the very concept of 'tourism destination' (Jovicic, 2017). They are being gradually accepted as a viable destination management approach based on an intensive ICTdriven interaction between destination stakeholders (Buhalis \& Amaranggana, 2014; IvarsBaidal, Celdrán-Bernabeu, Mazón, \& Perles-Ivars, 2017) and an intelligent decision-making drawn on tourism-related big data (Del Vecchio, 2017; Xiang \& Fesenmaier, 2017). Despite being a rather theoretical buzzword (Gretzel, Sigala, Xiang, \& Koo, 2015), SDs have received increasing attention from governments and DMOs, with policies being implemented in many destinations. Spain is one of the particular territories where the idea has permeated public institutions and businesses strategies in a higher degree (Femenia-Serra, 2018; Ivars-Baidal et al., 2017).

However, irrespective of the increasing stream of literature, empirical findings assessing the real impact of this approach in specific destinations are recent and rare (e.g. Buonincontri \& Micera, 2016; Del Vecchio \& Passiante, 2017; Khan, Woo, Nam, \& Chathoth, 2017), and usually only encompassing an external assessment of policies or data mining-based evaluations. More profound approaches that take into account different stakeholders' views are missing, and tourists' perspective is only taken in a limited scope (e.g. da Costa Liberato et al., 2018). Consequently, the real effects of smart destination policies remain largely 
unknown. The main aims of these policies and projects are creating better experiences and improving the destination marketing and management processes from a public-oriented standpoint (Buhalis \& Amaranggana, 2014; Gretzel, Werthner, Koo, \& Lamsfus, 2015; Wang et al., 2013). Acknowledging these research gaps, the objective of this paper is to discover whether and how smart destination strategies and smart solutions are transforming destinations management and tourists' experiences. This general objective can be divided into two specific ones: to find out SD effects on $(i)$ destination management and marketing and (ii) tourists' experiences. To pursue these objectives, the well-known destination of Benidorm is taken as a relevant case study. This destination has been recognised as the first at the national level to have a tourism intelligence system certified with UNE 166006:2011 standard (equivalent to ISO standards) and has successfully overcome the initial phase for being certified with the innovative standard UNE 178501:2015 for 'smart tourism destinations management system' by the Spanish Standardisation Agency (AENOR) (Segittur, 2017). Hence, Benidorm is close to be officially recognised as a smart destination thanks to this standardisation process. Furthermore, the real implementation of smart solutions and technological applications is granting Benidorm a firm reputation as SD.

Regarding tourists' experiences, this paper undertakes the critical task of interpreting how tourists perceive and use smart solutions as well as how these solutions transform their experiences in their multiple dimensions. With respect to destination management, smart destination strategies need to be concise about how each technological solution is supposed to enhance the performance of a destination in a determined scope. Therefore, this paper goes beyond the study of smart destinations through analyses of the main policies being implemented (e.g. Boes, Buhalis, \& Inversini, 2015, 2016; Micera, Presenza, Splendiani, \& Del Chiappa, 2013), to also include tourists and their experiences in the equation while keeping in mind the critical role of the DMO. 
This study makes a contribution on several levels. It provides a clear picture of how a traditional mass destination is transforming itself into a smart destination by developing a specific strategy and implementing technological solutions. Additionally, this research involves tourists and their experiences in the analysis of smart destination by taking an emic approach which prevents the usual rhetorical discourse, answering to the call for a more tourist-centric and action-oriented approach towards SDs. The obtained findings are significant for research on smart tourism because of their novelty and originality, but also for practitioners because of their manifold implications. Involving tourists extensively has revealed the need for rethinking smart destinations implementation.

The paper is structured as follows. First, it discusses the current state of research on smart destinations from a holistic perspective, to delve subsequently into the utilisation of smart solutions for destinations management and enhancement of tourist experiences. Second, the selection of Benidorm as a case study is explicated. Third, the employed methods and details of data collection and analysis processes are presented, followed by research findings. To conclude, a discussion of results and conclusions is provided together with implications for research, DMOs and policy makers. Finally, limitations are acknowledged and future research lines are proposed.

\section{Literature Review}

\section{Smart Tourism Destinations and Smart Solutions}

Smart destinations (SDs) can be characterised by some critical features that build up their 'smartness', such as their ability to harmonically employ different types of ICTs to allow a higher interconnection between all the stakeholders and a more informed decision-making (Buhalis \& Amaranggana, 2014; X. Wang, Li, Zhen, \& Zhang, 2016). A second major 
characteristic of smart destinations is their intensive use of data that provides them with an advanced understanding of tourists' behaviour and needs, thus opening new possibilities to offer better services and experiences in a more real-time and context-aware manner (Choe \& Fesenmaier, 2017; Xiang \& Fesenmaier, 2017). In a nutshell, smart destinations are those capable of encompassing cutting-edge technologies and exploitation of big data to develop an interconnection between the stakeholders, an intelligent decision-making, and consequently offer enhanced experiences in increased competitive destinations (Boes et al., 2015, 2016, Buhalis \& Amaranggana, 2014, 2015; Xiang \& Fesenmaier, 2017). They rely on intelligent systems (Gretzel, 2011), the Internet of Things (IoT) or cloud computing (Wang et al., 2013), among other technological advancements. As a result, a novel destination management approach is being built upon the manifold opportunities ICTs offer (Femenia-Serra, 2018; Ivars-Baidal et al., 2017). Nevertheless, smart destinations theoretical propositions and principles need to be specified into concrete, available and valuable solutions for destinations to implement from a public-oriented perspective, this is, 'smart solutions'. Following IvarsBaidal et al. (2017), smart solutions can be understood as technology-based applications and tools a smart destination DMO can employ to fulfil its objectives, namely enrich its visitors' experiences and its own management processes. This way, SDs combine the use of cuttingedge technologies with more consolidated and widespread ICTs to offer a wide range of smart solutions. According to this, in this paper an adaptation of the model provided by Ivars-Baidal et al. (2017) is taken as interpretative framework (Figure 1). 
Figure 1. Smart tourism destination solutions.

Own elaboration based on Ivars-Baidal et al. (2017)

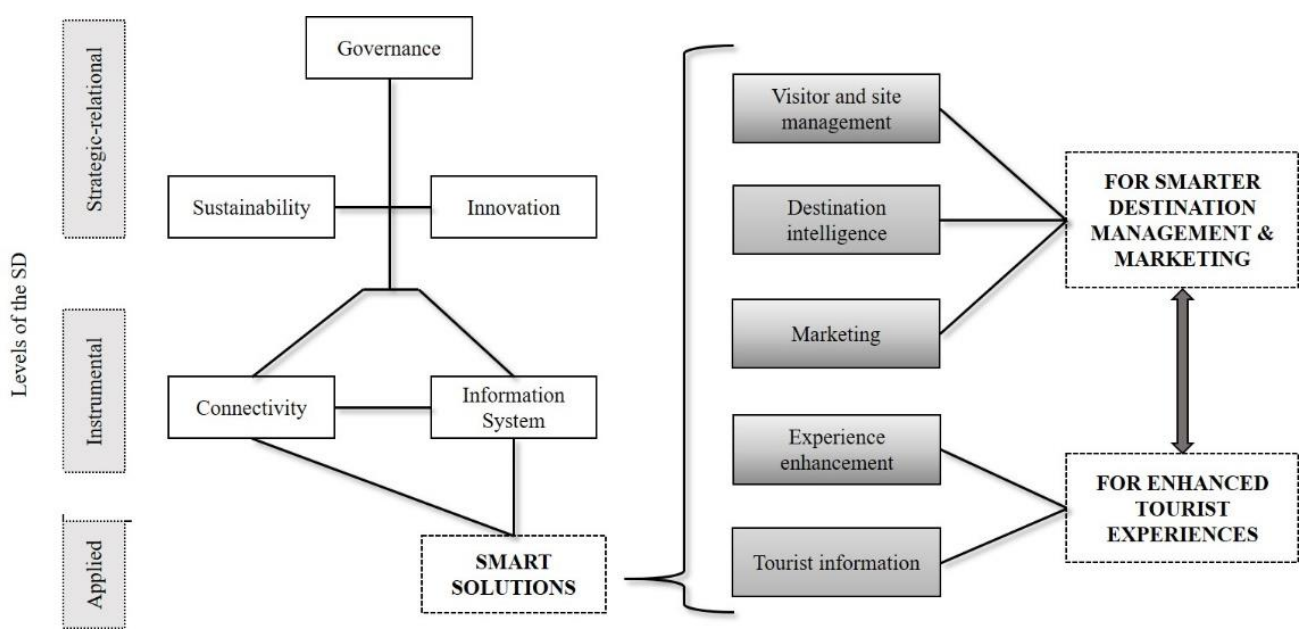

In their systemic understanding of smart destinations based on three interrelated levels (left side), Ivars-Baidal et al. (2017) introduce five scopes in which smart solutions might be applied. In this model, the application of smart solutions feeds the instrumental and strategic levels of the SD, enlightening the performance on these aspects. However, the concrete solutions are not clearly and systematically classified, and the five categories have blurred limits between them. Therefore, this paper groups smart solutions into two broader categories acknowledging two possible main objectives for their application, and goes into further detail by specifying concrete smart solutions. Based upon the holistic perspective provided by these authors and in several previous studies (Femenia-Serra, Perles-Ribes, \& Ivars-Baidal, 2018; Gretzel, Reino, Kopera, \& Koo, 2015; Gretzel, Zhong, \& Koo, 2016; Huang, Goo, Nam, \& Yoo, 2017), smart solutions include, among others: public ubiquitous Wi-Fi, big data analysis tools, intelligence dashboards, advanced DMO websites and blogs, QR codes and geotags, beacon technology, virtual and augmented reality, chatbots, social media actions, destination apps, drones, etc. It is the combination of all these technologies what builds up the smartness that can result into better experiences and optimised destination management. However, few studies (e.g. Buonincontri \& Micera, 2016; da Costa Liberato, Alén-González, \& de Azevedo Liberato, 2018) have addressed to date how DMOs, as leading entities of SDs (Gretzel, 
Werthner, et al., 2015), use smart solutions to $(a)$ improve their management processes and (b) enhance their tourists' experiences.

\section{Destination Management and Tourist Experiences in Smart Destinations}

On the one side, regarding destinations performance, smart solutions offer a range of possibilities to inform and boost destinations management, specially their marketing processes (Ivars-Baidal et al., 2017). Due to their institutional nature, in SDs DMOs are critical. DMOs are the only capable entity to deliver the required coordination and global perspective needed at destinations to succeed, and are in charge of delivering memorable experiences while ensuring residents' quality of life and sustainable development (Bornhorst, Ritchie, \& Sheehan, 2010). To improve their performance, smart destinations can use big data analytics, including tools for User-Generated Content (UGC) (Marine-Roig \& Anton Clavé, 2015), and specifically for social media (Del Vecchio, 2017), to generate valuable insights and business intelligence for destinations that may crystallise in destination management systems (Fuchs, Höpken, \& Lexhagen, 2014). In line with this, SDs are expected to develop a central intelligence platform or system that encompasses all the generated data by different stakeholders (Buhalis \& Amaranggana, 2014; X. Wang et al., 2016), and quantifies as much as possible travellers' behaviour (Choe \& Fesenmaier, 2017). Using tourists' credit card transaction data, monitoring bookings in real-time or employing sensors to measure different parameters are all part of this destination intelligence. These options are very much related to how innovative technologies can widen the 'knowledge-based destination' (KBD) conceptual approach (Cooper \& Sheldon, 2010; Racherla, Hu, \& Hyun, 2008). In respect of marketing, SDs strategies are articulated over the possibilities new channels offer, emphasising the combination of social media and mobile devices (Buhalis \& Foerste, 2015). Supported on these, using a last generation official website, state-of-the-art destination app, and combining an advanced use of social media are all a 'must' in a smart destination (Buonincontri \& 
Micera, 2016). Furthermore, from a prospective point of view, an evolution towards real-time data collection and exploitation through big data techniques for a data-driven management is expected (Ivars-Baidal et al., 2017).

On the other side, tourist experiences must be equally enhanced in SDs. However, tourist experiences, because of their complexity and its socially-constructed nature, are particularly fuzzy and hard to capture in any context. Tourist experience components, its spatial and temporal dimensions together with the diversity of tourist types mean they are highly subjective and varied (Uriely, 2005). Fusing the cognitive and affective perspectives, Mossberg (2007) argues experiences are a blend of elements that involve the consumers emotionally, physically, intellectually and spiritually" (p.61). All these dimensions of experiences are then interpreted and maybe translated into memories by the own experiencers (Volo, 2009). Supported on rich literature, Tussyadiah \& Zach (2012) deconstruct tourist experiences in four general dimensions: (1) sensory and physical, (2) affective, (3) cognitive and perceptual and (4) social, and one particular for their study context (en-route). Apart from the manifold dimensions composing the experience, a particularly complex matter which needs to be emphasised is their 'measurement', as experiences only completely accessible for the own person experiencing (Volo, 2009).

Despite their complexity, it seems clear that tourists' experiences have become increasingly mediated and enhanced by ICTs in many different contexts and during all trip stages (pre-trip, during trip and post-trip) (Tussyadiah \& Fesenmaier, 2009), fostering the co-creation process and the intensity of the experience (Neuhofer, Buhalis, \& Ladkin, 2015). Particularly relevant landmarks in the ICT-driven transformation and improvement of experiences have been the advent of social media (Munar \& Jacobsen, 2014; Xiang \& Gretzel, 2010) and smartphones (Wang, Xiang, \& Fesenmaier, 2014, 2016). Parallel to this progress, experiences are gradually transformed as technologies evolve and are able to perform more complex tasks, becoming 
this way smart. In their more applied perspective, smart technologies are defined as specific tools, products and services which add value by fostering higher connectivity, interaction, personalisation and co-creation levels (Neuhofer et al., 2015). This value can be created for both the tourist and the destination. Smart technologies are therefore the most advanced form of smart solutions and together with 'conventional' ICTs and devices controlled by users, can be applied in SDs to foster superior experiences. Besides, while in tourism much of the tourist experience depends upon businesses and how these co-create value with their customers, smart destinations are for the moment heavily public-driven and DMO-oriented. This is in line with the great responsibility placed on DMOs during the last years to use ICTs to improve tourists' experiences in the three stages of the trip (Buhalis, Leung, \& Law, 2011), and the need of tourism destinations to position themselves as innovative, modern places that make efforts to make their visitors' experiences more enjoyable through technological services (da Costa Liberato et al., 2018). Findings until now have emphasised smart technologies can contribute to a better overall travel experience (Lee, Lee, Chung, \& Koo, 2018), by fostering for instance a higher co-creation (Buonincontri \& Micera, 2016).

Nevertheless, tourists' perspective is missing from a richer, holistic standpoint, that sheds light on how smart solutions are transforming different dimensions of their experiences. Moreover, while much effort has been put on the benefits of ICTs for tourist experiences, less attention has been paid to the flip side or negative effects technologies might also produce (Neuhofer, 2016). This task is particularly necessary in contexts like smart destinations where connectivity and technological devices are omnipresent. Therefore it is advisable to understand tourist experiences from the very tourists' voice, allowing them to freely express subjectively their experiences through narratives (Tussyadiah, 2014), and to examine the potential benefits, but also disadvantages, of using smart solutions. In this context, the examination of how real destinations are applying this smart philosophy becomes relevant for 
getting to know what is being done beyond rhetorical discourse and the repercussion of these projects.

\section{Case Study Background: Benidorm as a Smart Destination}

Benidorm (70.470 inhabitants) is a sun and sand mass destination located in the province of Alicante, south-eastern Mediterranean coast of Spain. It emerged in the 1960s as a major international and national coastal resort and is characterised by an intensive use of land (highrise buildings), long stays ( $\overline{\mathrm{x}}: 5,6$ nights) and elevated occupancy rates throughout the year $(\overline{\mathrm{x}}$ : $75,96 \%$ ) in hotels. Moreover, it is the fourth Spanish destination in yearly hotel overnights after Barcelona, Madrid and San Bartolomé de Tirajana (National Statistics Institute -INE-, 2017). This has resulted in a successful destination with limited seasonality and a high dependence on the Spanish and British markets, accounting the latter for around $75 \%$ of foreign visitors overnights (Ivars-Baidal, Rodríguez, \& Vera, 2013).

Table 1. Benidorm tourist accommodation (2017)

\begin{tabular}{|c|c|c|c|}
\hline & Capacity $(n)$ & \multicolumn{2}{|c|}{ Overnights in $2017(n)$} \\
\hline \multirow{2}{*}{ Hotels } & \multirow{2}{*}{38.778} & \multirow{2}{*}{11.585 .630} & 4.932.752 Spanish $(\mathrm{S})$ \\
\hline & & & 6.652.878 Foreign $(\mathrm{F})$ \\
\hline \multirow{2}{*}{ Apartments } & \multirow{2}{*}{20.391} & \multirow{2}{*}{2.827 .130} & $478.328(\mathrm{~S})$ \\
\hline & & & $2.348 .802(\mathrm{~F})$ \\
\hline \multirow{2}{*}{ Camping } & \multirow{2}{*}{13.308} & \multirow{2}{*}{2.118 .340} & $162.947(\mathrm{~S})$ \\
\hline & & & $1.955 .393(\mathrm{~F})$ \\
\hline \multirow{2}{*}{ Total } & \multirow{2}{*}{72.477} & \multirow{2}{*}{16.531 .100} & $5.574 .027(\mathrm{~S})$ \\
\hline & & & 10.957.073 (F) \\
\hline
\end{tabular}

Own elaboration based on National Statistics Institute (2017)

Benidorm has gained notable attention among scholars due to its sustained success, with a clear focus on its competitiveness (Claver-Cortés, Molina-Azorín, \& Pereira-Moliner, 2007), degree of innovation (Perles-Ribes, Rodríguez-Sánchez, \& Ramón-Rodríguez, 2017), its evolution over time and efforts to renew and reposition the destination for new market 
segments (Ivars-Baidal et al., 2013; Soares, Ivars-Baidal, \& Gândara, 2015). However, during the last years, Benidorm has drawn attention in media and political sphere for its project to become 'the first smart destination' of Spain.

The destination DMO (known as Visit Benidorm) is leading the smart strategy of Benidorm. Visit Benidorm is the public-private partnership responsible for the marketing and management of the destination from a public-oriented standpoint and lobbies for the competitiveness of Benidorm and to protect the interests of all its members (VisitBenidorm, 2017). Moreover, Benidorm has enrolled the Spanish smart cities network (RECI) and is leading a regional project for developing smart destinations launched by the Valencian government together with the Valencian Tourism Technologies Institute (Invat.tur), which has just created in Benidorm the first technical office to assist destinations in their transition towards smartness. The destination has also recently been awarded with a four million euros funding line by the Spanish Ministry of Industry, Tourism and Digital Agenda to advance in its smart destination strategy (Benidorm City Council, 2018), and is implementing manifold state-of-the-art technological solutions. The strong collaboration of the DMO with private companies to develop the SD project, and its innovative character have made it a renowned case in the Spanish context, even being presented by the national agency Segittur as an example to follow in many countries (Egypt, Colombia...). Therefore, taking into account these circumstances and after an initial screening of other potential smart destinations, Benidorm was selected for being a representative case of a smart destination. 


\section{Methods}

\section{Research Strategy and Data Collection}

A case study research strategy is employed for this investigation. This empirical enquiry allows to investigate a 'contemporary phenomenon, in depth and within its real-world context' (Yin, 2014, p.16), thus reflecting reality while keeping a holistic perspective. It constitutes a consistent enquiry able to expand knowledge in emerging issues, building up theories for comprehending realities and supporting novel approaches with empirical evidence, helping this way to better explain phenomena and settling the bases for further investigations (Eisenhardt, 1989). The method has been widely used for evaluation of public policies and programmes (Yin, 2003), and therefore can be extremely useful for assessing the outcomes and efforts of destinations to become smart. Kitchin (2015) considers the absence of empirical case studies of specific initiatives is a shortcoming that inhibits making sense of smart cities, and the same applies to smart destinations initiatives, as few studies have evaluated the real impact of smart solutions on a local scale, particularly from the tourist perspective (Buonincontri \& Micera, 2016; da Costa Liberato et al., 2018).

To strengthen its validity, in this study multiple sources of evidence were employed and allowed to triangulate data (Yin, 2003, 2014). A threefold sequential qualitative method was employed (see Figure 2), consisting in (1) Documentary and secondary data analysis, (2) Indepth semi-structured interviews with DMO representatives and knowledgeable experts involved in the project, and (3) In-depth semi-structured interviews with tourists visiting Benidorm. This sequence of methods responds to the above-formulated general objective and specific objectives (SO). The first methodological phase enlightened how Benidorm is developing and implementing its smart strategy in a comprehensive manner. Drawing on this, the second phase was designed to obtain further, richer data. The interviews completed the picture of the smart destination project from the DMO perspective and offered findings 
regarding its effects on destination management and marketing (SO1), while they also helped to settle the bases for the third phase. In this last stage, the interviews with tourists provided a complementary perspective that allowed the comparison with the obtained results in phases one and two. The final phase resulted into rich data about effects of SD on experiences (SO2).

Figure 2. Research design

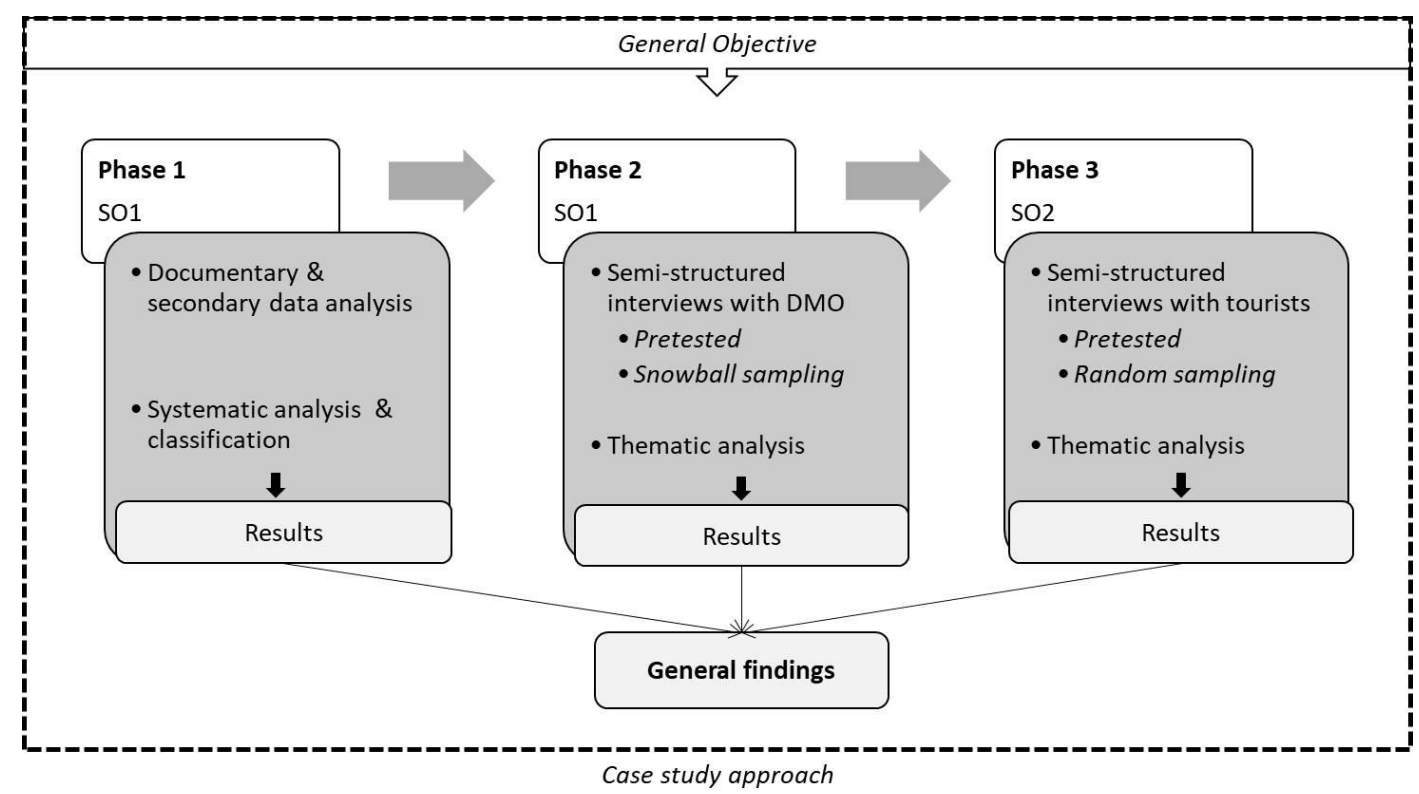

Documentary and secondary data analysis consisted in a systematic review of the existing public but also facilitated documents and data about the destination, its smart destination strategy and implemented technological smart solutions. Following, semi-structured in-depth personal interviews were performed with representatives of the DMO and experts involved in the project, and also with tourists visiting Benidorm. Interviews for both collectives were selected as the means of research for several reasons. On the one side, this method has been proved to be particularly fitted for gaining insight into policy making and destination management issues (e.g. Bornhorst et al., 2010; Ivars-Baidal et al., 2013; Stevenson, Airey, \& Miller, 2008). On the other side, there is also a clear quest for the use of tools like in-depth interviews to seize tourists' experiences from a deeper and naturalistic perspective (Tussyadiah, 2014). In line with this, interviews have been widely used to unveil travellers' 
experiences (e.g. McCabe, 2005; Tung \& Ritchie, 2011; Uriely, Yonay, \& Simchai, 2002), and particularly to explore the influence of ICTs over them (e.g. Buhalis \& Amaranggana, 2015; Neuhofer, 2016; Wang et al., 2014; 2016; Yoo, Tussyadiah, Fesenmaier, Saari, \& Tjøstheim, 2008). Thus, two different interviews guides were designed: one for the destination DMO and key knowledgeable informants, and another one for tourists. Both guides were reviewed by two different academic experts and pre-tested to ensure all the questions were well-formulated and fully understandable. The guides were re-adjusted according to the input from experts and pre-tests. The participants selection followed predetermined criteria and process in each case:

In the case of DMO representatives, snowball sampling was used after the initial contact. All the project leaders and knowledgeable experts were identified and interviewed, including: DMO manager, smart destination project leader, data analysis responsible, marketing responsible and a manager of a public institution (Invat.tur) who acts as a project advisor. This limited number of participants responds to the small size of the organisation and the suggested interviewees by the own participants (snowball sampling), but offered rich information for its direct involvement in the project from the beginning. In this case, the questions were aimed at obtaining their perspective on the smart project, implemented technological solutions and outcomes of this strategy regarding destination management, including marketing, as well as their impressions of the consequences for tourists.

In the case of the interviews with tourists, two criteria guided their selection: tourists needed to be eighteen years old or more, and to have spent at least two nights in Benidorm in their current visit. The latter condition prevented from interviewing visitors which still hadn't had time to 'experience' the destination and, potentially, its smart solutions. In line with the principles of the smart strategy of Benidorm, not only tech-savvy tourists qualified for the interviews but rather any tourist who belonged to a target segment for Benidorm (families, 
elderly travellers, groups of friends...). While not having any expectation to be representative of a wider population, a strategic sampling of participants was performed to reflect the existing heterogeneity within the demand (see table 2). Therefore, selection replicated the real diversity among Benidorm tourists (age, sex, nationality, type of accommodation) as the smart destination strategy expects all tourists to become immersed and use smart solutions. Consequently, it was necessary to understand whether, how and why (or why not) tourists' experiences are actually being shaped by these solutions.

Tourists were randomly approached by facilitators at the hall and common areas of tourist accommodations, and if meeting the requisites, invited to participate. Three different hotels, one campsite and one aparthotel served as locations. The research purpose was explained to each participant and formal consent was obtained to record the interview, which was conducted in Spanish or English depending on the tourist' preference. A total of 34 tourists were finally interviewed, including 2 from the pre-test. The initial questions of the interview were aimed at obtaining the tourists' perception and use of ICTs for their trips and experiences, while the questions progressively evolved towards their experience in Benidorm, delving deeply into whether and how Benidorm smart solutions influenced their experience. Their perspective around Benidorm as a destination using intensively technologies was also gathered. Participants were finally asked about basic demographic information. The interview kept a focused but flexible scheme to explore emerging issues. Through these interviews, participants' perspective, experiences and meaning given to the phenomena under study was acquired (Corbin \& Strauss, 2008). 
Table 2. Interviewees' socio-demographic profile

\begin{tabular}{|c|c|c|c|c|c|}
\hline No. & Gender & Age group & Nationality & Education & Accommodation \\
\hline 1 & Female & $35-60$ & British & Secondary & Hotel \\
\hline 2 & Female & $35-60$ & British & Higher & Hotel \\
\hline 3 & Male & $>60$ & Spanish & Higher & Hotel \\
\hline 4 & Female & $35-60$ & British & Higher & Hotel \\
\hline 5 & Female & $35-60$ & British & Higher & Hotel \\
\hline 6 & Male & $18-34$ & British & Secondary & Hotel \\
\hline 7 & Male & $18-34$ & American & Secondary & Hotel \\
\hline 8 & Male & $>60$ & Spanish & Secondary & Hotel \\
\hline 9 & Female & $35-60$ & Spanish & Higher & Hotel \\
\hline 10 & Female & $35-60$ & Spanish & Higher & Hotel \\
\hline 11 & Female & $>60$ & Icelandic & Higher & Hotel \\
\hline 12 & Female & $>60$ & British & Secondary & Hotel \\
\hline 13 & Female & $35-60$ & British & Secondary & Hotel \\
\hline 14 & Male & $35-60$ & Spanish & Higher & Hotel \\
\hline 15 & Female & $18-34$ & Spanish & Higher & Hotel \\
\hline 16 & Female & $35-60$ & Spanish & Secondary & Hotel \\
\hline 17 & Male & $35-60$ & British & Secondary & Hotel \\
\hline 18 & Male & $>60$ & Spanish & Primary & Hotel \\
\hline 19 & Male & $35-60$ & British & Higher & Camping site \\
\hline 20 & Female & $>60$ & Dutch & Secondary & Camping site \\
\hline 21 & Male & $>60$ & British & Primary & Camping site \\
\hline 22 & Male & $35-60$ & Spanish & Secondary & Camping site \\
\hline 23 & Male & $>60$ & Dutch & Secondary & Camping site \\
\hline 24 & Male & $35-60$ & Spanish & Higher & Camping site \\
\hline 25 & Female & $35-60$ & Spanish & Higher & Camping site \\
\hline 26 & Female & $18-34$ & British & Secondary & Camping site \\
\hline 27 & Female & $35-60$ & Irish & Higher & Aparthotel \\
\hline 28 & Female & $35-60$ & British & Secondary & Aparthotel \\
\hline 29 & Male & $18-34$ & British & Secondary & Aparthotel \\
\hline 30 & Female & $18-34$ & French & Higher & Aparthotel \\
\hline 31 & Male & $35-60$ & Spanish & Higher & Aparthotel \\
\hline 32 & Male & $18-34$ & British & Higher & Aparthotel \\
\hline 33 & Female & $35-60$ & Spanish & Primary & Aparthotel \\
\hline 34 & Male & $35-60$ & Spanish & Primary & Aparthotel \\
\hline
\end{tabular}

Own elaboration

\section{Data Analysis}

The 39 interviews were recorded, transcribed verbatim and analysed using Atlas.ti 7.0 () software, lasting an average of $17^{\prime} 30^{\prime \prime}$ in the case of tourists, and $1 \mathrm{~h} .16^{\prime}$ in the case of DMO representatives. Data collection and analysis were intertwined in time to enrich the process while performing theoretical sampling to complete the picture of the phenomenon under study and explore all the detected dimensions with further data (Corbin \& Strauss, 2008). Interviews stopped when saturation was reached, meaning that all concepts were well-defined, 
and all their dimensions explored. To analyse data, an inductive and iterative thematic analysis was performed following procedures suggested by Miles \& Huberman (1994) and Corbin \& Strauss (2008): First, transcriptions were read and re-read. Second, text was subject to an open, line-by-line coding looking for preliminary, lower-level codes, giving time to deep reflection. In this process memos and diagrams were constantly done to relate data and concepts, while codes were named according to their meaning. Memoing helped to reflect, make questions about data, explain and develop concepts by critically analysing the meanings, feelings and issues behind respondents' words. Third, codes were gradually grouped into broader categories according to axial coding principles. This helped to identify underlying patterns (i.e. 'pattern coding') (Miles \& Huberman, 1994), while putting into relationship the different concepts. Fourth, the coding process was repeated with new data and compared constantly with the code book, fusing some codes and eliminating others. Codes were refined until final themes were fully developed. The adoption of a constant comparative approach towards data analysis entangled the constant check-coding and re-coding (Glaser \& Strauss, 1967). By following this consistent procedure, a higher reliability of the analysis was

obtained, and replication was facilitated. In the process, notes taken during field work were also decisive to interpret interviewees' narratives, to double-check meaning and reinforce interpretation. Moreover, the authors were in contact with the involved people in the project and the destination itself for long periods, which helped to interpret the obtained data (Vallés, 2003).

\section{Findings}

Results are organised in subsections according to the formulated specific objectives, namely discovering the effects of smart destination strategies on: $(i)$ destination management and marketing, and (ii) tourists' experiences. Additionally, the first subsection delves into smart 
solutions as the applied outcome of the strategy making an impact on both scopes and connecting them. Part of findings are presented in the form of themes emerged during interviews and their analysis, and are explored in their variation and complexity to give sense to the individuals' perspectives and experiences (Corbin \& Strauss, 2008).

\section{Smart solutions provision}

The findings reveal the development and use by Benidorm of smart solutions as the applied side of its SD project. A total of 24 smart solutions, including three under development, have been identified in secondary data analysis and interviews with DMO representatives. Following the adaptation of the above-presented framework from Ivars-Baidal et al. (2017), Benidorm smart solutions can be classified into two categories, as reflected in figure 3.

Figure 3. Benidorm smart solutions. Own elaboration

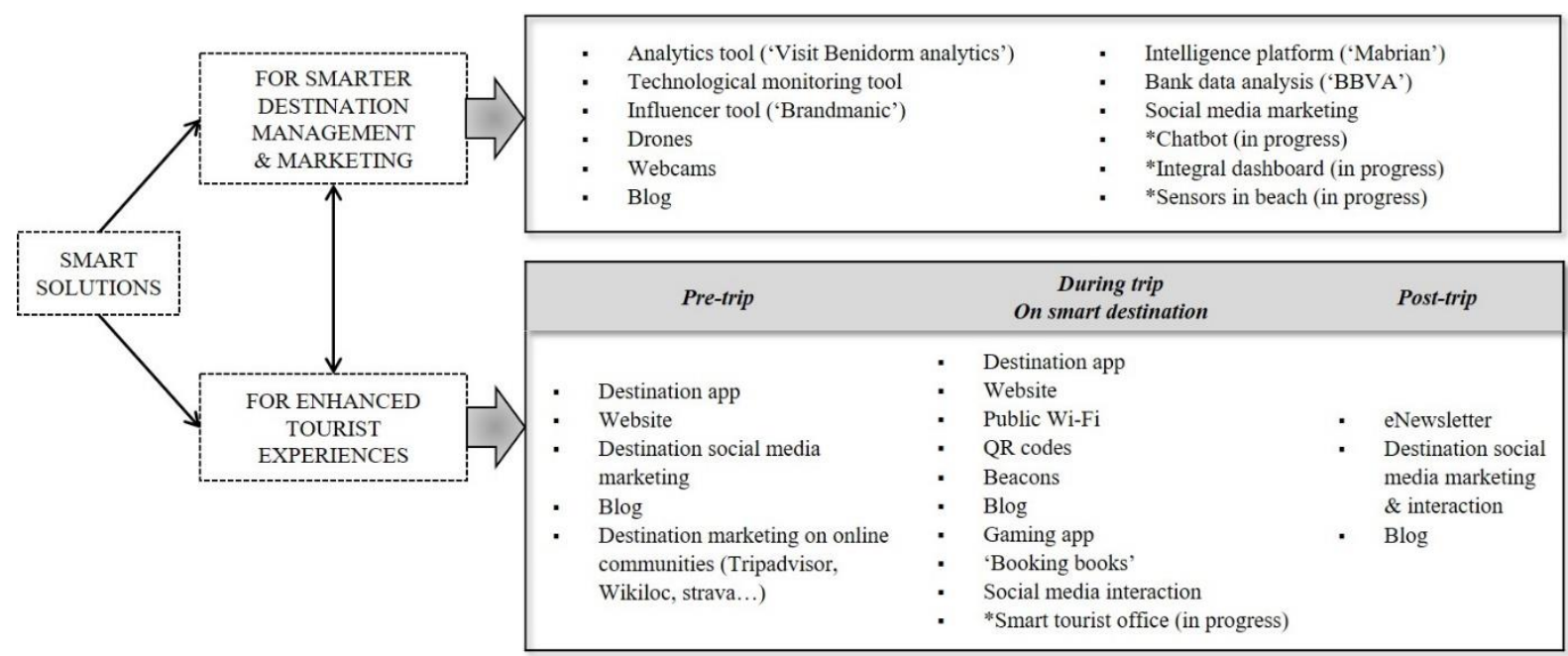

Benidorm uses smart solutions for different purposes. Regarding smart destination management and marketing, Benidorm has adopted a combination of intelligence and marketing tools to get an optimal knowledge of tourists, to address different market segments and to improve decision making, among other objectives. Regarding tourist experience enhancement, conventional ICTs but also more advanced smart services and tools are being employed to facilitate tourists a more pleasant stay: public $\mathrm{Wi}-\mathrm{Fi}$, beacons, apps, actions on 
social media, etc. As revealed by informants, the principles guiding the implementation of these solutions are a 'strong collaboration with private companies' (most of all start-ups), a 'limited spending in each solution', a 'design based on current needs', and the need of 'obtaining data from each solution'. According to informants, smart solutions are carefully planned because of the risks of 'random investments', 'technology obsolescence', 'legal limitations', and 'difficulty to plan in the long term'. Technology is clearly understood by project leaders as a mean but not an end, capable at the same time of transforming the whole functioning of a destination fighting to remain competitive.

"It looks like a contradiction, but the best you can do to reposition a mature destination is to use new technologies” (Marketing manager)

This reflection introduces a new approach to the restructuring process of coastal destinations (Agarwal, 2002; Agarwal \& Shaw, 2007), identifying smartness as an innovative way to reposition mature destinations. In this sense, it is interesting to analyse to what extent a smart destination strategy, as a result of a new understanding of destinations as innovation systems fuelled by ICTs, can affect the lifecycle of a tourist destination.

\section{Smart Destination: Management and Marketing}

Narratives from the involved agents in the project have revealed five main themes with respect to the impacts of the smart project regarding destination management and marketing.

\section{Data-driven Knowledge}

As reported by informants, knowledge about tourists is now more profound and includes aspects which would not be possible to obtain without the application of smart solutions. It is perceived that only in a smart destination this is feasible:

"To offer tourists a better service we need to know them, what they want and what they do in the city, what they say, how and when they come, what they buy or don't buy during their holidays [...] Only in 
smart destinations, thanks to all that technology and innovation we're able to have a greater knowledge of what those tourists do and why" (DMO manager)

Informants agree that a major outcome of the project and the utilisation of smart solutions is a better, deeper knowledge in many scopes that massive data permits. A 'data-driven knowledge' is hence obtained in Benidorm that was not possible before.

"Wi-Fi isn't just a service we're offering, it's a tool that gives us data to work. Now we know about the tourists who come, their typology (sic), nationality, age, what they say on social media, or what they don't say! [...] What we're trying here is to trace the tourist back, to know where they come from, how they come here, how much they spend and how... all that's what we're trying to measure" (Data manager)

The application of the latest techniques to social media analysis also gives the smart destination 'a clear picture of tourists', their feelings and perceptions:

"I can see on social media those opinions and ratings because we're measuring through semantic analysis what they're saying about our attractions. And this is a massive improvement because nothing was quantified before, so that's already a progress" (Data manager)

Based on this gathering and data analysis, reports are being created periodically for all the city departments to be aware of the destination reality. Furthermore, new public tenders include the obligation of hired companies to provide the obtained data in their operations to the city council and tourist board. This is granting Benidorm a 'public access and control of data' to be used in its marketing and management. Hence, it seems that the destination is obtaining clear benefits from data while it is also facing some challenges regarding the difficulties big data analysis entangles for a DMO. Informants acknowledge these limitations but are positive about the forthcoming progresses.

\section{Data-driven Marketing and Decision Making}

The availability and analysis of data grants the smart destination a marketing strategy based on real knowledge of tourism demand. Marketing decisions are now 'informed, efficient and 
organised' according to the detected needs through data analysis. Previous work to marketing actions is now deeper, planned and aimed to specific objectives.

"When you really start to know the tourist, it helps you to point and shoot into the right direction. For instance, if we are going to do an online campaign in Belgium, we already have data about that market from social media, the type of tourist, what they like... Then it's something efficient and makes you save money" (Data manager)

This way, there has been a total transformation of the destination marketing thanks to the knowledge and tools which Benidorm uses. The omnipresence and active promotion on social media has made the destination profiles very popular and users' interaction is object of deep analysis for future actions. A key aspect in this new 'data-driven marketing' is the use of analysis tools and data experts. Benidorm has developed together with a start-up a social media analysis solution, named 'Visit Benidorm analytics', which provides managers with key information for marketing decisions based on a simpler, straightforward interface:

"It took so much effort before to monitor social media and we lost a lot of time gathering all the 'likes' and so on. Then we developed, with a limited budget, a tool that allows us to see data in a very visual way, so we can make decisions. It integrates the data from different social media and the reports can be personalised by date, time periods, used hashtags, etc.” (DMO manager)

Agents involved in the project also report that Benidorm has developed a clearly 'pro-active attitude' towards novelties in the marketing field. Managers have a strategy for each online channel adapted to its characteristics and ensure that they are present in any growing platform in the market. 'Flexibility' and 'quickness' to adapt to such a changing environment seem key for the smart destination.

“There's a great diversity within online media and things change fast. Some years ago, for example, blogs were very important, but Google is introducing in 2019 a change in its algorithms that will prioritise video and pictures in results. Then it will be very important to have those keywords on your photos and video sound... We're always alert for new trends. We're always trying out the new features of platforms, 
like instastories, and trying out new social media, getting verified profiles just in case they succeed in the future" (Marketing manager)

A remarkable example of this 'innovative attitude' towards online marketing is the use Benidorm makes of influencers. The criteria for their selection depart from the detected needs on demand studies, and are frequently addressed towards profiles in which Benidorm is interested. This constitutes a clear example of how the smart destination, through a detailed analysis of data, can detect specific needs and address them through the right marketing strategies while saving costs and time.

Apart from marketing, other management decisions are being made thanks to data, granting a higher 'efficiency', as informants report saving cost and time and 'being specific' about objectives in their decisions. Participants' narratives reveal that data has allowed a more 'sound, provable and transparent' decision making in the tourist board. Data analysis is supplying the destination managers with key information that guides their actions and is even capable of influencing policy makers actions, as the following quote illustrates:

\footnotetext{
"According to official statistics of hotels and National Statistics Institute, Italian tourists in Benidorm are almost non-existent. However, when we started to work with data seven or eight months ago, I detected that during the summer the Italian language was the fifth more used in social media conversations in Benidorm. Then, by analysing the geolocation data of these posts, we discovered that most of these Italian tourists were sleeping in illegal tourist apartments because they were tweeting and posting from residential buildings, not hotels. We made a report with that and issued it to the regional tourism administration [...] Since then, they've made more inspections in apartments. We can have influence this way, making evident what we believe or know" (Data manager)
}

At the same time, innovative tools are also being used for decision-making. In this regard, the DMO has created together with another start-up, a 'technology monitoring system' which helps them to follow what other competitor destinations are doing regarding technology implementation, but also specific products like running, golf or music events. This automatic 
search tool facilitates benchmarking practices and makes managers more efficient. However, there is room for improvement in the use of data for decisions. In this regard, the lack of a central technological platform means a limitation.

"We want to have a big platform or 'smart brain' in which we can dump all the data and all the information can be coordinated. Not only public data, but also from the companies which work with the city, so we can have that dashboards to help us make quick decisions" (DMO manager)

\section{Internal Coordination and Leadership}

The interviewees' narratives show the benefit for internal coordination among destination managers that the smart project has rendered. Participants underline the importance of having a common, long-term objective instead of short-termed promotion campaigns. Communication between different city council areas linked to tourism has improved, and the relatively small size of the DMO makes the interchange of ideas very dynamic. The crosscutting nature of tourism makes almost any department to be implied in the SD project.

\footnotetext{
"Everybody in the administration is working in a different way because we're giving them new tools and new systems that are making them change their functioning. It's something very original that had never been done before...putting the health department, sports and tourism in the same box is new. And that's very cool" (Project leader)
}

This way, the project is led by the tourist board/DMO but it is affecting the way the whole city council works and understands tourism. While this is an advantage, it also generates challenges:

\footnotetext{
“Becoming a smart destination and managing it isn't an easy task, because it's not like a city in which tourism is just one sector among many others. Here everything is tourism. There are 22 local departments connected to tourism. We have to face that complexity too" (Project leader)
}

The coordination within the public management of the destination requires a good relationship between the city council and DMO, and it seems that thanks to the smart destination project this 'co-dependence' is being reinforced. 
"There is now a much closer relationship between them (the city council and DMO). You can see them together in many more presentations, meetings, projects...they act as interchangeable agents and I think that at the technical level, and as a team, they are working more united" (Project advisor)

In line with this, leadership has been strengthened and has become more visible in both the tourist board and the city council for the right progress of the smart project. Leadership is therefore linked to a clear 'Political commitment' with the smart destination. The mayor's office supports and embraces the smart destination strategy as part of its own political project.

\section{Public-private Partnership and Innovativeness}

Informants highlight the benefits of a closer collaboration between public institutions and private companies at the destination and the implication in the project of a business intelligence consulting firm which helps to link the public interest with private initiatives. Participants agree that private businesses, in coalition with the DMO, are having a key role in constructing the smart destination:

"We're very lucky that there's a tourist board with a high percentage of private partners that know about the smart destination project. They follow its progress, they support it and even reinforce it" (Project leader)

This alliance is possible because of business volume, strength and unity of the destination private sector, particularly hoteliers. Apart from this, and because of the smart project, the destination is now opened to new types of private investments, which has allowed a 'shared co-responsibility' in the funding of smart solutions thanks to win-win agreements between the DMO and technology companies. Benidorm has self-proclaimed as a lab for start-ups and innovative companies that want to test their technology in the destination. Local, but also national start-ups are developing technological solutions for example for beach management, tourist information (chatbots), social media analytics, etc. Project leaders assume the risk of innovating in this field and support this approach: 


\begin{abstract}
"The DMO wanted to open Benidorm to any kind of prove and beta testing. They wanted to position Benidorm in this field, and although the destination has always collaborated with academia, now there is also a new stream of companies which are interested in investing in Benidorm because of technology" (Project advisor)
\end{abstract}

This strategic coupling with technology companies has allowed for instance a zero-cost implementation of public Wi-Fi for the tourist board and city council thanks to an agreement with a private telecom company and sponsors who have funded the project in exchange of advertisement. The same has happened with the implementation of beacon technology.

\title{
Destination Image and Certification
}

Informants report that one of the main outputs of the smart destination project is the 'repositioning' of Benidorm public image, especially among tourism professionals, administration and companies. Thanks to the progressive recognition of Benidorm as a pioneer $\mathrm{SD}$, the reputation of the destination is changing and public awareness is growing.

"Benidorm is already recognised as a smart destination, which implies that it's now positioned in the territorial map, even at an international level. Benidorm is now present in new forums and is becoming an innovation hub and tech lab. That was impossible three years ago" (Project leader)

In consonance with this, the standardisation process Benidorm is following to become the first official smart destination according to the Spanish standardisation agency AENOR is reinforcing that recognition. Certification will ensure Benidorm the best starting place for any future public funding lines launched by the different administrations.

"Benidorm is the most advanced destination to be certified as a smart destination by AENOR. That doesn't have to be an objective for all destinations because it's almost unachievable, but for Benidorm it's more possible than ever. It's going to position Benidorm internationally" (Project leader)

Nevertheless, while the destination image is evolving among tourism professionals and some forums, the problem lies in casting this change and making it visible for tourism demand. This 
is an arduous task that will require further implication by different agents and a continuity of the strategy over a long time.

"It's so hard to change that stigma of Benidorm. Tourists have the perception Benidorm is the same mass, cheap and bad-looking destination as always. All the efforts regarding offer segmentation and quality aren't seen by the mass. Fighting that is so difficult $[\ldots]$ although they will gradually perceive some improvements in the services they get" (Project advisor)

\section{Smart destination: Tourists' Experiences}

The second part of the findings is related to the perception of tourists regarding Benidorm as a smart destination and smart solutions repercussion for their experiences. Tourists' narratives have revealed four main themes in this regard.

\section{Awareness of Smart Solutions}

Many informants reported they were unaware of the existence in the destination of smart solutions that are usable by them. This happened even though some tourists considered themselves 'tech-savvy', as in the cases of informants \#4, \#11, \#27 or \#32. Several smart solutions like beacons, QR codes or gaming app hadn’t been used by any interviewee. The lack of advertisement was noted by participants as the main reason for this situation, although most participants acknowledged they hadn't been looking specifically for any type of technological solution that could be handy for them.

"I wish I had known about the free Wi-Fi because then I could have listened to any music when I was running on the beach, instead of downloaded music I had on my phone... and I never really thought about visiting Visit Benidorm or try to see if there was anything... If they promoted it or something like that, then it would make it easier because I know a lot about technologies and I didn't see anything about Visit Benidorm” (\#27, Irish female, 40 y/o)

"I think most people come here as a package holiday, through a tour operator. Perhaps tour operators should make that publicity, like explaining when you get the information about your pack, that apart from the map you can use all these technologies, and you can use this app or website to get more from your 
destination and experience... because I wouldn't go and google 'technologies in Benidorm' and I don't think the majority of people would either. If you see it in front of you in black and white, you're more likely to act on it" (\#4, British female, 45 y/o)

Even being unaware, these informants' narratives show a positive attitude towards all the existing technologies and a unanimous agreement on the potential benefit these solutions can render tourist experiences. This 'perceived usefulness' was due to the potential 'access to richer information', 'discovery of unknown places' or 'better sharing of experience'. Those unaware of the existence of smart solutions agreed with the need to further promote them.

\section{Need and Willingness to Use Smart Solutions}

Participants expressed in some cases a limited need and wish to use technological solutions because of factors such as 'previous knowledge of the destination' (which is high in many cases), 'short stays' and 'type of destination', perceived as being a sun and sand destination where limited amount of information is required. Moreover, informants referred to the needlessness of using the provided smart solutions because of having their own sources of information, connection possibilities and devices. Consequently, some informants felt it was unnecessary to use the smart solutions Benidorm was offering, or felt they were redundant with the sources they already had. This was particularly true for national visitors, as happened in the cases of informants \#10,\#14 and \#34.

\footnotetext{
"We don't use the public Wi-Fi because we have our own, very good, data, and besides we don't like using that when we're walking around. We aren't connected all the time and we know the place" (\#34, Spanish male, 48 y/o)
}

“To come here and enjoy it I don't need any technology. I have the beach, the pool...I really don't need anything else. Sometimes I use the Wi-Fi when I'm at the hotel and my own data...but let's be sincere: There aren't many things to visit here. You don’t need a lot of information” (\#16, Spanish female, 52 y/o) 
"When I was doing research to come here, a mobile application advert popped up from the Benidorm website and gave me the option to download it, but I didn't really feel it was necessary" (\#19, British male, $39 \mathrm{y} / \mathrm{o})$

In line with this, other participants showed a proactive use of technologies when travelling to other type of destinations but not for Benidorm. This is the case of informants \#3 and $\# 8$, or \#24, who is a fervent user of travel blogs and social media to look for information but had been visiting to Benidorm since the 1990s and had never used any information source because he just wanted to relax. This is linked to the will expressed by many informants to 'disconnect from any technology' when they are on a trip, as they felt they already used them too intensively in their jobs and daily life.

"Technologies are very useful, but when I arrive to my destination I just want to disconnect from everything. The less, the better. I leave my smartphone in my room. I feel I'm already going crazy at my job because of technologies, so I just want to forget it all” (\#14, Spanish male, 45 y/o)

Apart from the need to disconnect from routine, many informants point out to the time and effort required to use technologies, like informant \#10 when stating that:

"If you have to share your pictures, write comments and rate services all the time...you're just paying attention to your smartphone instead of the experience itself" (\#10, Spanish female, 43 y/o)

But most of all, many informants mention 'privacy and security concerns' as an important factor that influences their use of smart solutions and other technologies for trips. Recent scandals affecting social media companies (mentioned by informants \#5, \#6, \#11, \#17) and the change in European legislation regarding data protection (informants \#4, \#8, \#32) emerge as new driving forces of this concern.

“I've heard about the Facebook issue, you know... and since then I haven't used Facebook so much and don't give my personal information, photos and sharing as before... I don't do it anymore. Everything is too open." (\#11, Icelandic female, 69 y/o)

"It's very positive to access these technologies when you travel: all the information, the speed... but all 
this means you have to facilitate a lot of data like your bank account, your email and other stuff. You don't know where these data go or to whom they give them" (\#8, Spanish male, 65 y/o)

\section{Positive Impact on Experiences}

Still, while there is a partial awareness of the existence of technological tools and in some cases a limited need or wish to employ them, for those making use, the result seems to be positive according to their narratives. Most known and used solutions include the public WiFi, social media interaction with DMO, and official smart website. Particularly, the use of these solutions in combination with their own devices and sources was, according to the informants, 'easy' and 'convenient'. Informants marked that thanks to these they could 'save time and effort' and allowed them to get 'richer information' in the right time and place.

"I think all these technologies Benidorm is using are positive. They make your life easier as a user, like when you're looking for information. Not everybody is able to go to a tourist office when it's open and wait for their turn... I still remember that time when you had to wait in a line to buy a tourist card or get a map...new technologies mean more time, accessibility and tranquillity" (\#10, Spanish female, 43 y/o)

"I follow Visit Benidorm on social media because it keeps me to date: what's going on, the weather, if there's a fiesta coming up, they say when some place opens so you can try the new bars or restaurants... so I find it useful for me before coming to know what's going on or what I can do" (\#26, British female, $33 \mathrm{y} / \mathrm{o})$

Participants also underline the benefits of these technologies to help them 'sharing and reexperiencing', as well as 'navigating', 'making unplanned decisions' and 'discovering unknown places'. Accordingly, tourists get more meaningful experiences and obtain the appropriate information to discover unexpected sights, making quick decisions or planning on the go, among other benefits.

\footnotetext{
"We use the website to look for information, points of interest, and if we need to, tickets for the water park or something like that. We always buy it once we're here because we decide on the go, we don't
} 
plan our holidays because you don't know what's going to happen when you have a baby" (\#23, Spanish male, $35 \mathrm{y} / \mathrm{o})$

"I wanted to find a bar where they had nice tapas, so I could go to TripAdvisor and see the reviews. I could log into the public Wi-Fi to see whether that restaurant was good or not" (\#26, British female, 33 y/o)

"I think because this is quite a big place, and a lot of people who come here wouldn't know the other beach, so this kind of technology might move people to other areas of the city and discover things that they don't think about Benidorm [...] I've seen for instance that you can go on the internet and you have cameras that show the beaches, and that's very nice and you can actually think 'wow it looks lovely there', so that was a good thing" (\#5, British female, 52 y/o)

For other tourists, the availability of these technologies made their experience more 'comfortable and safe' thanks to improved communication possibilities.

"My daughter has attention and concentration difficulties and I knew that when she went off, she had her phone, and she knew how to use Google Maps to get back to the hotel and also was able to message me back. I wasn't worried because we were able to get Wi-Fi everywhere while she was out. I think that if I hadn't had that I would have been really stressed for a lot of the holiday, so that was REALLY good." (\#27, Irish female, 40 y/o)

\section{Negative Impact on Experiences}

Together with the positive impact for experiences, some informants also indicated that the use of smart solutions didn't offer such value for them, or at least in some dimensions of their experiences. One of the main outcomes that emerges from narratives is the 'loss of human interaction' related to the utilisation of technologies for certain purposes. For most informants, technologies need to be combined with human interaction, both when relating to companies and trip companions. This issue goes beyond tourism for some travellers and influences many facets of their life. 
"Before arriving to a place or hotel I like to do my research on the internet. But when I arrive here I prefer to be assisted by a person, face to face, rather than to interact with a computer. To get information is okay, but I like personal treatment, human contact” (\#16, Spanish female, 52 y/o)

"I normally don't look for a lot of information on the internet. I prefer to talk to people who have been here, and for specific things like 'how to get there' I use my phone. Also to find all the details and actually planning the trip" (\#32, British male, 28 y/o)

"Forgetting the holiday industry, it annoys me tremendously that I can't speak to anyone, they want you to do it all online. Lots of times you can't speak to people and I find that annoying” (\#22, British male, 75 y/o)

Informants also report that in some situations the use of technologies diminishes 'spontaneity' and the 'discovery of unexpected places'. The 'repetition of behaviours' linked to the popularisation of certain places because of experience sharing on social media and eWOM makes the experience less 'authentic' for some interviewees.

\footnotetext{
"You almost don't blindly explore things, so you miss the little gems...if we use Google Maps to go to the old town all the time, we just follow what it says, instead of trying to find out ourselves, and in doing that we miss some of the cultural sites and buildings and things like that... so in some ways it's good, because it makes you more efficient, but you ruin or loss that side of just going around and exploring, so you miss that factor of getting lost, but enjoying getting lost” (\#32, British male, 28 y/o)

"The bad side of technologies is that some spots have become just too 'touristy' because everybody is posting how great these places are and we end up going to the same places and doing the same" (\#24, Spanish male, 39 y/o)
}

The 'loss of privacy', apart from being a potential inhibitor to use technologies (privacy concerns), is a consequence seen as unavoidable and negative by many informants when using smart solutions. This is linked somehow by participants to another consequence of the sharing of personal data: 'information overload' and 'invasive marketing'. These are seen as a direct result of the so-called 'personalised services and information'. 
"I just gave my data to this hotel... so I'm sure tomorrow they will start to annoy me with more and more information like offers and so on. That bombardment is what bothers me" (\#8, Spanish male, 65 y/o)

"There's so much information that if you need anything, you can just look for it...but getting automatically all those offers and information, no thanks" (\#30, French female, 24 y/o)

Finally, informants report that in some cases the use of technologies has created in them 'overdependence' on these tools and 'inability to disconnect', which has a negative impact in their experience, as they feel this does not allow them a total detachment from their daily lives:

"I always spend too much time on my phone, so from that point of view that's not a positive thing. And because I could access the cricket whenever I wanted to, I've spent all of my trip looking at what was happening, the score, and checking back at home" (\#27, Irish female, 40 y/o)

\section{Discussion and conclusions}

This study has aimed to discover whether and how smart tourism destinations strategies and solutions enhance destination management and marketing as well as tourists' experiences. By taking as a relevant case the Spanish destination of Benidorm, findings have revealed how the smart project alters these two scopes. These findings are illustrated in figure 4. 
Figure 4. Smart destination effects on destination management and tourist experiences.

Own elaboration

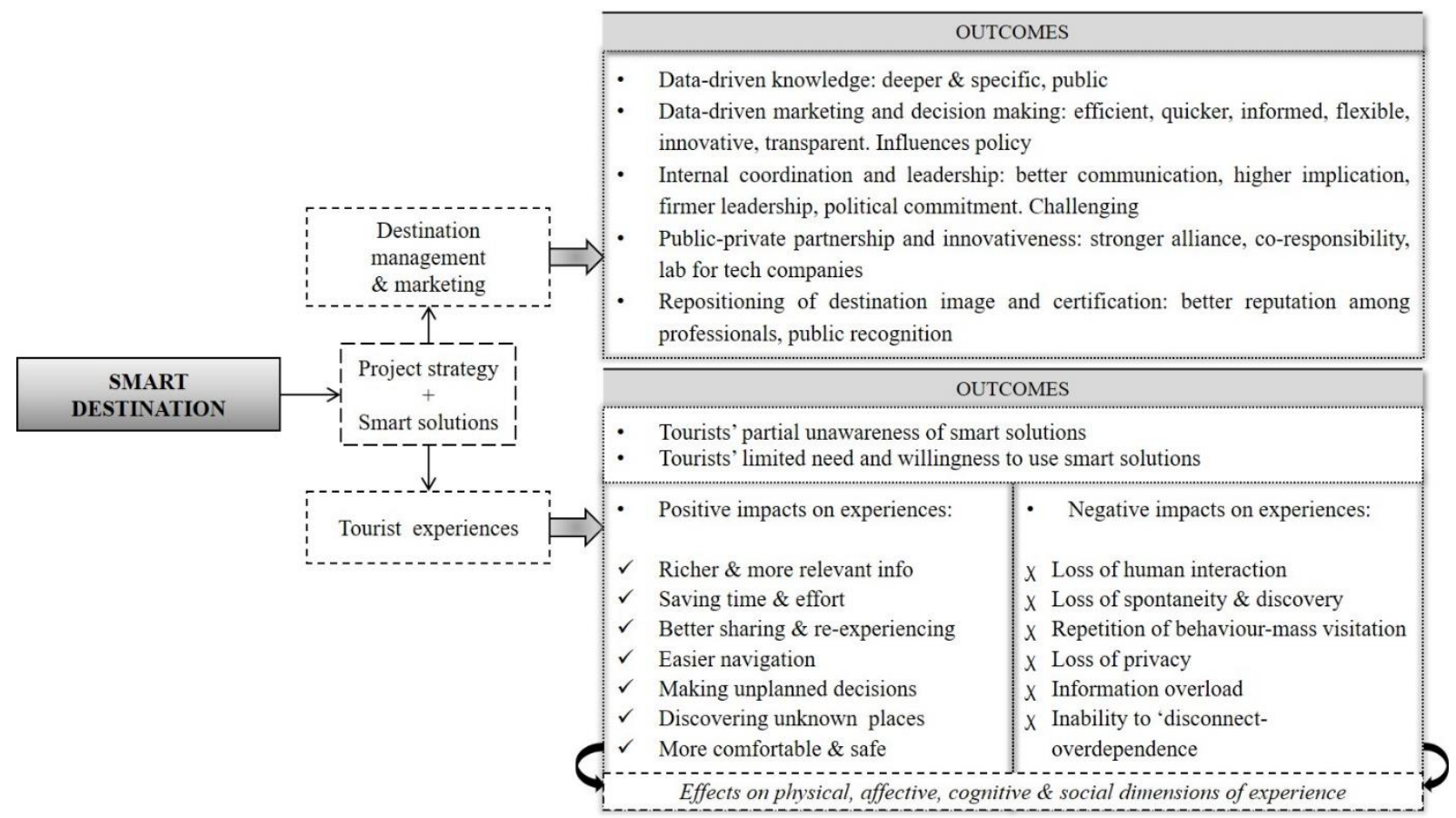

The used sequence of methods has helped to understand to what extend different stakeholders and factors are interwoven in smart destinations. The implications of DMO actions for tourists and vice versa are apparent, but need to be further recognised. Findings show that DMO decisions, particularly regarding smart solutions, have a direct impact on tourist experiences in the SD. Accordingly, tourists' narratives offer valuable information for DMOs and can serve to improve design and implementation of smart projects in order to minimise negative effects and maximise positive outcomes. This way, this study results pose a number of implications on the theoretical but also managerial level as well as interesting directions for future research.

\section{Theoretical implications}

The obtained results support the benefits of smart destination strategies argued in literature (Boes et al., 2015; Buhalis \& Amaranggana, 2014; D. Wang et al., 2013; X. Wang et al., 
2016, among others) and confirm technological smart solutions are fully capable of improving destination management as the concrete applications that materialise the 'smart spirit' (IvarsBaidal et al., 2017). The usefulness of big data analysis for smart destinations and their DMOs (Marine-Roig \& Anton-Clavé, 2015; Xiang \& Fesenmaier, 2017) is here further acknowledged, for example regarding tourists and their behaviour (Choe \& Fesenmaier, 2017). This confirms big data is essential for decision making in SDs. Data grants smart destinations the required knowledge and their coupling with ICTs shapes the perfect scenario for real 'knowledge-based destinations' (Racherla et al., 2008). Our findings indicate that thanks to data-driven knowledge and decision making, smart destinations improve their performance, but at the same time some concerns emerge among DMOs regarding data governance, concurring with previously identified threats and challenges for smart tourism construction (Gretzel, Sigala, et al., 2015). However, findings also reveal unexpected outcomes of the smart strategy application, namely the repositioning of the destination image and a higher innovativeness and openness towards private investments, which could be partly due to the political push in the Spanish case (Femenia-Serra, 2018). In a sense, the smart destination project is conceived as a new rejuvenation strategy for Benidorm. This assumption introduces a new approach to the study of the evolution of destinations and their restructuring and rejuvenation strategies connected with innovation and the impact of ICTs in knowledgebased destinations. It is interesting to analyse whether the development of a smart tourist destination strategy is a matter of efficiency or goes further and, in terms of Evolutionary Economic Geography (EEG) (Brouder, Anton \& Ioannides, 2016; Sanz-Ibáñez \& Anton, 2014), can modify the path dependence of the destination (path plasticity) or, even, generate new trajectories based on smart developments.

This study also contributes to a better understanding of the DMO role in smart destinations, and emphasises the importance of its leadership, as these organisations have proved to be 
capable of developing new functionalities and creating partnerships in this complex environment (Gretzel, Werthner, et al., 2015). With respect to destination marketing, our findings suggest that the analysis of UGC allows the smart destination a more informed, flexible and efficient marketing strategy, concurring with the proposals of Marine-Roig \& Anton-Clavé (2015). Within the exploitation of big data, this study confirms social media data as one of the main sources smart destinations can use for improving their actions (Del Vecchio, 2017). Benidorm has demonstrated a masterful handling of this possibility, which has rendered the destination a clear competitive advantage. All these findings reinforce the idea of smart destinations as relying on data for their functioning as their differential factor from traditional destinations.

Nevertheless, while the smart destination strategy has a clear positive impact on the destination management and marketing scopes (it works), this study offers a valuable demand-centric approach with findings that recommend situating the tourist at the very centre of smart destinations and poses more theoretical implications. Tourists' narratives suggest the consequences of this project and solutions on tourist experiences are complex. First, unawareness of technological solutions existence stands as a critical challenge. Besides, voluntary non-use of solutions is a multifaceted reality studies and destinations must also deal with when assessing the impact of smart solutions. This unveils the limited information regarding tourists' wish to actively participate in smart destination and confirms previous findings which point out to this fact in specific demand segments (Femenia-Serra et al., 2018). These factors need further recognition in smart tourism research, as frequently adoption and use of technologies is taking for granted.

When exploring how solutions shaped experiences, findings show a clear benefit in acquiring information, efficiency in making decisions (time and effort), sharing of experience or navigating the destination, among others. These benefits are similar to those found by Wang 
et al. $(2014,2016)$ for smartphone use, and while more quantitative in nature and focused on applications, are consistent with to those of da Costa Liberato et al. (2018). Public Wi-Fi for instance allows tourists to get relevant information whenever they need it and makes them feel more comfortable and efficient by simply making possible, for instance, to look for a specific restaurant or use Google Maps to get back to the hotel. Similarly, thanks to smart destination website, tourists can plan their activities on the go and find for example tickets for theme parks. Thus, findings reveal that because of smart solutions, tourists obtain an experience which is more personalised (Buhalis \& Amaranggana, 2015), interactive, informed and efficient (Lee et al., 2018), and a better response to their needs during the different stages of their trips. This endorses the previously demonstrated capacity of ICTs to add value to tourist experiences in multiple levels and trip stages (Neuhofer et al., 2015; Tussyadiah \& Fesenmaier, 2009). However, our results complement this perspective, since they offer novel insights about the flip side of smart solutions. Tourists indicate the negative consequences of the smart destination strategy on tourist experiences, pointing out to factors such as privacy, limited interaction with other human beings, information overload or dependence on technologies. They think the overuse of certain technologies is making them less social and spontaneous, more dependent, unable to disconnect and feel they are losing control over their own personal information. The constant use of navigation tools available because of ubiquitous connectivity makes tourists lose the sense of exploration, while the spread of online reviews and social media has contributed to massive visitation to certain spots. These results contribute to complete the picture of the increasingly recognised drawbacks of technologies on experiences, which point out to the barrier they imply for a total disconnection, true living of the experience and the sense of addiction they create (Neuhofer, 2016). Similarly, other authors have recently emphasised connected experiences can make tourists lose time in certain situations, create unrealistic expectations of communication and 
rely too much on connectivity (Tanti \& Buhalis, 2016). Being continuously connected creates in tourists great levels of anxiety in times or locations where connectivity is unavailable or impossible, particularly when there is lack of control over this situation (Paris, Berger, Rubin, \& Casson, 2015). Thus, our findings reveal that smart solutions do have consequences on the physical, affective, cognitive and social dimensions of experiences (Tussyadiah \& Zach, 2012), altering this way the overall travel experience. Technological solutions change for example how tourists move around and navigate the destination (i.e. physical dimension), how they feel about opinions and sharing of information (i.e. affective), how they obtain, process and use information (i.e. cognitive) and how they relate to other people (i.e. social). These findings respond to the call for a better understanding of tourists' ICT use in complex contexts and enlighten the potential damage smart systems can cause to tourist experiences (Gretzel, 2011). The presented results contradict some expectations reflected in smart literature, and go beyond technology adoption studies to also explore effects on experiences, contributing to this growing stream of literature. Tourists' own perspective and trust in technologies constitutes a notable gap in smart tourism research (Gretzel, Werthner, et al., 2015). It is hoped these findings shed some light on this regard.

\section{Practical implications}

This research results provide a solid foundation for a better understanding of how smart destination strategies are affecting tourists and destinations functioning, and offer critical implications for destination managers and policy makers. On the one hand, it seems clear that smart destination strategies render destinations benefits in their management and marketing in scopes such as decision making, knowledge, innovation or public image. Therefore, following the example of Benidorm might be beneficial for other mass and mature destinations in a similar situation. On the other hand, the perspective provided by tourists suggests the need for a more user-centric design of smart solutions that considers their actual perception and 
attitude towards but also use of these technologies. By doing so, destination managers will ensure a successful implementation of technological solutions aimed at a direct enhancement of tourist experiences. The value provided by some solutions in information search, planning and sharing of experience has to be reinforced, and these solutions better promoted among tourists. This could result into a higher degree of awareness and use. Nonetheless, the flip side of technology and its potential to destruct value in certain situations also needs to be carefully considered. Managers need to plan smart destination areas and situations where disconnection is possible. A combination of both types of spaces (i.e. connected and disconnected) is possible and desirable (Dickinson, Hibbert, \& Filimonau, 2016).

\section{Limitations and directions for future research}

The presented findings need to be interpreted carefully. First, because results are contextdependent, they are not generalisable. While this case study has helped to enlighten the theoretical foundations of smart destinations (Eisenhardt, 1989) and to assess the real outcomes of policy implementation in this regard (Yin, 2003), different types of destinations (i.e. cultural, urban, rural...) might have alternative ways to implement smart strategies and solutions. Concerning destination management and marketing, it is possible that the same strategy does not work for other destinations with different attributes and in different cultural contexts. Regarding tourists, the intrinsic characteristics of visitors might also influence how they perceive and use technological solutions, living this way, dissimilar experiences depending on the destination and trip characteristics (i.e. repeat visitation factor, types of attractions, etc.). In line with this, it is necessary to analyse how response to smart solutions and effects on experiences vary according to sociodemographic factors. Age, technological skills or cultural background could be influential in shaping tourists' attitudes and behaviours and could even serve to DMOs to stablish scalable strategies for a diverse typology of visitors. Moreover, further research is needed to contrast the presented findings in different 
settings. Investigations should also focus on exploring how enjoyable and detrimental effects of smart solutions on experiences are negotiated by individuals and coped with through different strategies. The transformation of experiences due to these technologies will need to be analysed longitudinally as technology progresses and new devices, functionalities and factors appear.

Acknowledgements: Research carried out within the project 'Analysis of planning processes applied to smart cities and smart tourism destinations. Balance and methodological proposal for tourist spaces: Smart Tourism Planning' (CSO2017-82592-R) under the Spanish National R\&D\&I Plan and Grant no. BES-2015-073909, funded by the Ministry of Economy, Industry and Competitiveness.

The authors would like to thank all the people who participated in this research.

\section{References}

Agarwal, S. (2002). Restructuring seaside tourism. The resort lifecycle. Annals of Tourism Research, 29, 5-55

Agarwal, S., \& Shaw, G. (2007). Managing coastal tourism resorts. A global perspective. Clevedon: Channel View

Benidorm City Council. (2018). El pleno aprueba el proyecto con el que Benidorm concurrirá al programa Red.es. Retrieved February 21, 2018, from http://benidorm.org/comunicacion/es/articulo/el-pleno-apruebael-proyecto-el-benidorm-concurrira-al-programa-redes

Boes, K., Buhalis, D., \& Inversini, A. (2015). Conceptualising Smart Tourism Destination Dimensions. In I. Tussyadiah \& A. Inversini (Eds.), Information and Communication Technologies in Tourism 2015 (Vol. 28, pp. 391-403). Cham: Springer. http://doi.org/10.1016/S0160-7383(01)00012-3

Boes, K., Buhalis, D., \& Inversini, A. (2016). Smart tourism destinations: ecosystems for tourism destination competitiveness. International Journal of Tourism Cities, 2(2). http://doi.org/10.1108/IJTC-12-2015-0032

Bornhorst, T., Ritchie, J. R. B., \& Sheehan, L. (2010). Determinants of tourism success for DMOs \& destinations: An empirical examination of stakeholders' perspectives. Tourism Management, 31(5), 572589. http://doi.org/10.1016/j.tourman.2009.06.008

Brouder, P., Anton Clavé, S., \& Ioannides, D. (Eds.). (2016). Tourism destination evolution. New York, NY: Routledge.

Buhalis, D., \& Amaranggana, A. (2014). Smart tourism destinations. In Z. Xiang \& I. Tussyadiah (Eds.), Information and Communication Technologies in Tourism 2014 (pp. 553-564). Cham: Springer. http://doi.org/10.1007/978-3-319-03973-2

Buhalis, D., \& Amaranggana, A. (2015). Smart Tourism Destinations Enhancing Tourism Experience Through Personalisation of Services. In I. Tussyadiah \& A. Inversini (Eds.), Information and Communication Technologies in Tourism 2015 (pp. 377-389). Cham: Springer.

Buhalis, D., \& Foerste, M. (2015). SoCoMo marketing for travel and tourism: Empowering co-creation of value. Journal of Destination Marketing \& Management, 4(3), 1-11. http://doi.org/10.1016/j.jdmm.2015.04.001

Buhalis, D., Leung, D., \& Law, R. (2011). eTourism: Critical information and communication technologies for tourism destinations. In Y. Wang \& A. Pizam (Eds.), Destination Marketing and Management: Theories and Applications (pp. 205-224). Wallingford: CAB International. http://doi.org/10.1079/9781845937621.0000

Buonincontri, P., \& Micera, R. (2016). The experience co-creation in smart tourism destinations: a multiple case analysis of European destinations. Information Technology \& Tourism, 16(3), 285-315. http://doi.org/10.1007/s40558-016-0060-5

Choe, Y., \& Fesenmaier, D. R. (2017). The Quantified Traveler: Implications for Smart Tourism Development. In Z. Xiang \& D. R. Fesenmaier (Eds.), Analytics in Smart Tourism Design (pp. 65-77). Switzerland: Springer. 
Claver-Cortés, E., Molina-Azorín, J. F., \& Pereira-Moliner, J. (2007). Competitiveness in mass tourism. Annals of Tourism Research, 34(3), 727-745. http://doi.org/10.1016/j.annals.2007.03.010

Cooper, C. \& Sheldon, P. (2010): Knowledge management in tourism: from databases to learning destinations. In Pearce, D. G., \& Butler, R. (Eds.). Tourism research: a 20-20 vision (pp. 215-227). Oxford: Goodfellow Publ.

Corbin, J., \& Strauss, A. (2008). Basics of Qualitative Research. Thousand Oaks: Sage Publications.

da Costa Liberato, P. M., Alén-González, E., \& de Azevedo Liberato, D. F. V. (2018). Digital Technology in a Smart Tourist Destination: The Case of Porto. Journal of Urban Technology, 25(1), $75-97$. http://doi.org/10.1080/10630732.2017.1413228

Del Vecchio, P. (2017). Creating value from Social Big Data: Implications for Smart Tourism Destinations. Information Processing \& Management, (October), 0-1. http://doi.org/10.1016/j.ipm.2017.10.006

Del Vecchio, P., \& Passiante, G. (2017). Is tourism a driver for smart specialization? Evidence from Apulia, an Italian region with a tourism vocation. Journal of Destination Marketing and Management, 6(3), 163-165. http://doi.org/10.1016/j.jdmm.2016.09.005

Dickinson, J. E., Hibbert, J. F., \& Filimonau, V. (2016). Mobile technology and the tourist experience: (Dis)connection at the campsite. Tourism Management, 57, 193-201. http://doi.org/10.1016/j.tourman.2016.06.005

Eisenhardt, K. M. (1989). Building Theories from Case Study Research. Academy of Management Review, 14(4), 532-550.

Femenia-Serra, F. (2018). Smart Tourism Destinations and Higher Tourism Education in Spain. Are We Ready for This New Management Approach? In B. Stangl \& J. Pesonen (Eds.), Information and Communication Technologies in Tourism 2018 (pp. 437-449). Cham: Springer. http://doi.org/https://doi.org/10.1007/9783-319-72923-7_33

Femenia-Serra, F., Perles-Ribes, J. F., \& Ivars-Baidal, J. A. (2018). Smart destinations and tech-savvy millennial tourists: hype versus reality. Tourism Review, (Forthcoming). http://doi.org/https://doi.org/10.1108/TR-022018-0018

Fuchs, M., Höpken, W., \& Lexhagen, M. (2014). Big data analytics for knowledge generation in tourism destinations - A case from Sweden. Journal of Destination Marketing and Management, 3(4), 198-209. http://doi.org/10.1016/j.jdmm.2014.08.002

Glaser, B. G., \& Strauss, A. L. (1967). The discovery of grounded theory: strategues for qualitative research. London: Transaction Publishers.

Gretzel, U. (2011). Intelligent systems in tourism. A Social Science Perspective. Annals of Tourism Research, 38(3), 757-779. http://doi.org/10.1016/j.annals.2011.04.014

Gretzel, U., Reino, S., Kopera, S., \& Koo, C. (2015). Smart Tourism Challenges. Journal of Tourism, 16(1), 4147. http://doi.org/10.1108/JTF-12-2014-0023

Gretzel, U., Sigala, M., Xiang, Z., \& Koo, C. (2015). Smart tourism: foundations and developments. Electronic Markets, 25(3), 179-188. http://doi.org/10.1007/s12525-015-0196-8

Gretzel, U., Werthner, H., Koo, C., \& Lamsfus, C. (2015). Conceptual foundations for understanding smart tourism ecosystems. Computers in Human Behavior, 50, 558-563. http://doi.org/10.1016/j.chb.2015.03.043

Gretzel, U., Zhong, L., \& Koo, C. (2016). Application of smart tourism to cities. International Journal of Tourism Cities, 1(3), 216-233. http://doi.org/http://dx.doi.org/10.1108/IJTC-08-2014-0014

Huang, C. D., Goo, J., Nam, K., \& Yoo, C. W. (2017). Smart Tourism Technologies in Travel Planning: The Role of Exploration and Exploitation. Information \& Management, (In press). http://doi.org/10.1016/j.im.2016.11.010

Ivars-Baidal, J. A., Celdrán-Bernabeu, M. A., Mazón, J.-N., \& Perles-Ivars, Á. F. (2017). Smart destinations and the evolution of ICTs: a new scenario for destination management? Current Issues in Tourism, In press(October), 1-20. http://doi.org/10.1080/13683500.2017.1388771

Ivars-Baidal, J. A., Rodríguez, I., \& Vera, J. F. (2013). The evolution of mass tourism destinations: New approaches beyond deterministic models in Benidorm (Spain). Tourism Management, 34, 184-195. http://doi.org/10.1016/j.tourman.2012.04.009

Jovicic, D. Z. (2017). From the traditional understanding of tourism destination to the smart tourism destination. Current Issues in Tourism. http://doi.org/10.1080/13683500.2017.1313203

Khan, S. M., Woo, M., Nam, K., \& Chathoth, K. P. (2017). Smart City and Smart Tourism: A Case of Dubai. Sustainability . http://doi.org/10.3390/su9122279

Kitchin, R. (2015). Making sense of smart cities: addressing present shortcomings. Cambridge Journal of Regions, Economy and Society, 8(1), 131-136. https://doi.org/10.1093/cjres/rsu027

Lee, H., Lee, J., Chung, N., \& Koo, C. (2018). Tourists' happiness: are there smart tourism technology effects? Asia Pacific Journal of Tourism Research, 23(5), 486-501. http://doi.org/10.1080/10941665.2018.1468344 
Marine-Roig, E., \& Anton Clavé, S. (2015). Tourism analytics with massive user-generated content: A case study of Barcelona. Journal of Destination Marketing \& Management, 4(3), 162-172. http://doi.org/10.1016/j.jdmm.2015.06.004

McCabe, S. (2005). "Who is a tourist?": A critical review. Tourist Studies, 5(1), 85-106. http://doi.org/10.1177/1468797605062716

Micera, R., Presenza, A., Splendiani, S., \& Del Chiappa, G. (2013). SMART Destinations: new strategies to manage tourism industry. In 8th International Forum on Knowledge Asset Dynamics: Smart growth: Organizations, cities and communities (IFKAD) (pp. 1405-1422). Zagreb: Emerald Group Publishing Limited. http://doi.org/http://dx.doi.org/10.1108/MBE.26717daa.001

Miles, M. B., \& Huberman, A. M. (1994). Qualitative Data Analysis (2nd ed.). Thousand Oaks: SAGE Publications.

Mossberg, L. (2007). A Marketing Approach to the Tourist Experience. Scandinavian Journal of Hospitality and Tourism, 7(1), 59-74. http://doi.org/10.1080/15022250701231915

Munar, A. M., \& Jacobsen, J. K. S. (2014). Motivations for sharing tourism experiences through social media. Tourism Management, 43, 46-54. http://doi.org/10.1016/j.tourman.2014.01.012

National Statistics Institute. (2017). Hospitality and Tourism Data. Retrieved from http://www.ine.es/dyngs/INEbase/es/categoria.htm?c=Estadistica_P\&cid=1254735576863

Neuhofer, B. (2016). Value co-creation and co-destruction in connected tourist experiences. In A. Inversini \& R. Schegg (Eds.), Information and communication technologies in tourism 2016 (pp. 779-792). Cham: Springer.

Neuhofer, B., Buhalis, D., \& Ladkin, A. (2015). Smart technologies for personalized experiences: a case study in the hospitality domain. Electronic Markets, 25, 243-254. http://doi.org/10.1007/s12525-015-0182-1

Paris, C. M., Berger, E. A., Rubin, S., \& Casson, M. (2015). Disconnected and unplugged: Experiences of technology induced anxieties and tensions while traveling. In Information and Communication Technologies in Tourism 2015 (pp. 803-816). Springer.

Perles-Ribes, J. F., Rodríguez-Sánchez, I., \& Ramón-Rodríguez, A. B. (2017). Is a cluster a necessary condition for success? The case of Benidorm. Current Issues in Tourism, 20(15), 1575-1603. http://doi.org/10.1080/13683500.2015.1043247

Racherla, P., Hu, C., \& Hyun, M. Y. (2008). Exploring the role of innovative technologies in building a knowledge-based destination. Current Issues in Tourism, 11(5), 407-428. http://doi.org/10.1080/13683500802316022

Sanz-Ibáñez, C. \& Anton Clavé, S. (2014). The evolution of destinations: towards an evolutionary and relational economic geography approach. Tourism Geographies, 16(4):563-579. doi: $10.1080 / 14616688.2014 .925965$

Segittur. (2017). Benidorm, an example of smart destination. Retrieved February 20, 2018, from http://www.destinosinteligentes.es/benidorm-ejemplo-destino-inteligente/

Soares, J. C., Ivars-Baidal, J. A., \& Gândara, J. M. (2015). La evolución de destinos turísticos litorales consolidados. Análisis comparado de Balneario Camboriú (Brasil) y Benidorm (España). Anales de Geografia de La Universidad Complutense, 35(2), 143-166. http://doi.org/10.5209/revAGUC.2015.v35.n2.50118

Stevenson, N., Airey, D., \& Miller, G. (2008). Tourism Policy Making:: The Policymakers' Perspectives. Annals of Tourism Research, 35(3), 732-750. http://doi.org/http://dx.doi.org/10.1016/j.annals.2008.05.002

Tanti, A., \& Buhalis, D. (2016). Connectivity and the consequences of being (dis) connected. In A. Inversini \& R. Schegg (Eds.), Information and Communication Technologies in Tourism 2016 (pp. 31-44). Cham: Springer.

Tung, V. W. S., \& Ritchie, J. R. B. (2011). Exploring the essence of memorable tourism experiences. Annals of Tourism Research, 38(4), 1367-1386. http://doi.org/10.1016/j.annals.2011.03.009

Tussyadiah, I. P. (2014). Toward a Theoretical Foundation for Experience Design in Tourism. Journal of Travel Research, 53(5), 543-564. http://doi.org/10.1177/0047287513513172

Tussyadiah, I. P., \& Fesenmaier, D. R. (2009). Mediating Tourist Experiences. Access to Places via Shared Videos. Annals of Tourism Research, 36(1), 24-40. http://doi.org/10.1016/j.annals.2008.10.001

Tussyadiah, I. P., \& Zach, F. J. (2012). The role of geo-based technology in place experiences. Annals of Tourism Research, 39(2), 780-800. http://doi.org/10.1016/j.annals.2011.10.003

Uriely, N. (2005). The tourist experience. Conceptual developments. Annals of Tourism Research, 32(1), 199216. http://doi.org/10.1016/j.annals.2004.07.008

Vallés, M. S. (2003). Técnicas cualitativas de investigación social. Reflexión metodológica y práctica profesional. Madrid: Síntesis.

VisitBenidorm. (2017). Visit Benidorm: City and Beaches. Retrieved February 19, 2018, from http://www.visitbenidorm.es/

Volo, S. (2009). Conceptualizing experience: A tourist based approach. Journal of Hospitality Marketing \& 
Management, 18(2-3), 111-126. http://doi.org/10.1080/19368620802590134

Wang, D., Li, X. R., \& Li, Y. (2013). China's "smart tourism destination" initiative: A taste of the servicedominant logic. Journal of Destination Marketing \& Management, 2(2), 59-61. http://doi.org/10.1016/j.jdmm.2013.05.004

Wang, D., Xiang, Z., \& Fesenmaier, D. R. (2014). Adapting to the mobile world: A model of smartphone use. Annals of Tourism Research, 48, 11-26. http://doi.org/10.1016/j.annals.2014.04.008

Wang, D., Xiang, Z., \& Fesenmaier, D. R. (2016). Smartphone Use in Everyday Life and Travel. Journal of Travel Research, 55(1), 52-63. http://doi.org/10.1177/0047287514535847

Wang, X., Li, X. R., Zhen, F., \& Zhang, J. (2016). How smart is your tourist attraction?: Measuring tourist preferences of smart tourism attractions via a FCEM-AHP and IPA approach. Tourism Management, 54, 309-320. http://doi.org/10.1016/j.tourman.2015.12.003

Xiang, Z., \& Fesenmaier, D. R. (2017). Big Data Analytics, Tourism Design and Smart Tourism. In Z. Xiang \& D. R. Fesenmaier (Eds.), Analytics in Smart Tourism Design (pp. 299-307). Switzerland: Springer.

Xiang, Z., \& Gretzel, U. (2010). Role of social media in online travel information search. Tourism Management, 31(2), 179-188. http://doi.org/10.1016/j.tourman.2009.02.016

Yin, R. K. (2003). Applications of Case Study Research (2nd ed.). Thousand Oaks: SAGE Publications.

Yin, R. K. (2014). Case Study Research. Design and Methods (5th ed.). Thousand Oaks: SAGE Publications.

Yoo, Y., Tussyadiah, I. P., Fesenmaier, D. R., Saari, T., \& Tjøstheim, I. (2008). Emergent distributed narratives in spatiotemporal mobility: An exploratory study on mobile 2.0 services. Proceedings of the Annual Hawaii International Conference on System Sciences, 1-10. http://doi.org/10.1109/HICSS.2008.143 